УДК 792.82(477)

Лук'яненко Катерина Аркадіївна, аспірантка, Київський національний університет культури і мистецтв, https://orcid.org/0000-0003-1490-4601 katechoreography@gmail.com

\title{
ХОРЕОГРАФІЧНИЙ СИМФОНІЗМ У КОНТЕКСТІ ОНОВЛЕННЯ УКРАЇНСЬКОГО БАЛЕТНОГО ТЕАТРУ (50-60-ті рp. ХХ ст.)
}

Мета статті - виявити специфіку інтегрування принципів хореографічного симфонізму в українському балетному театрі за часів хрущовської «відлиги». Методологія дослідження. Застосовано метод історизму (для дослідження процесу впровадження танцювального симфонізму в контексті особливостей культурно-історичної ситуації); типологічний метод (що посприяв виявленню специфіки побудови та композиції танцювальних форм); метод порівняльного аналізу (для співставлення методів розкриття образу героя через танець в балетних виставах на сценах українських театрів 50-60-х pp. ХХ ст.); метод стильового підходу (спрямований на визначення специфіки хореографічної структури балетних постановок) та ін. Наукова новизна. Розглянуто поняття «хореографічний симфонізм» у контексті новаторства творчих пошуків українських балетмейстерівпостановників 1950-1960-х рр.; виявлено та охарактеризовано методи хореографічного симфонізму як нової форми балетної вистави, а також визначено внесок українських балетмейстерів А. Шекери, В. Вронського, М. Трегубова, Н. Скорульської та І. Ковтунова в розвиток художньо-образних форм вітчизняного балетного мистецтва. Висновки. Дослідження хореографічного симфонізму в контексті оновлення українського балетного театру 50-60-х рр. XX ст., на прикладі постановок провідних вітчизняних балетмейстерів, виявило, що окремі балетні вистави, масові чи сольні партії побудовані на розробці хореографічних тем із їх паралельним розвитком та протиставленням; поєднанні хореографічних тем з музичними; єдності музичної та хореографічної форм; проведенні ритмічності в тактовому та тематичному відношенні; збігу хореографічноемоційного та звуко-емоційного підйому, а також колоритності інструментування та танцювальних рухів. Елементи балетного симфонізму, що проявляються передусім у специфічній побудові композиції, активно інтегрувалися українськими балетмейстерами задля досягнення інноваційної хореографічної виразності на основі танцю та відповідно до образності, структури музичної партитури.

Ключові слова: хореографічний симфонізм, балет, балетмейстер, композиція, розкриття образу. искусств

Лукьяненко Екатерина Аркадьевна, аспирантка, Киевский национальный университет культурь и

Хореографический симфонизм в контексте обновления украинского балетного театра (50-60-е гг. хx в.)

Цель статьи - выявить специфику интегрирования принципов хореографического симфонизма в украинском балетном театре во времена хрущевской «оттепели». Методология исследования. Применен метод историзма (для исследования процесса внедрения танцевального симфонизма в контексте особенностей культурно-исторической ситуации); типологический метод (который помог выявлению специфики построения и композиции танцевальных форм); метод сравнительного анализа (для сопоставления методов раскрытия образа героя через танец в балетных спектаклях на сценах украинских театров 50-60-х гг. ХХ в.); метод стилевого подхода (направлен на определение специфики хореографической структуры балетных постановок) и др. Научная новизна. Рассмотрено понятие «хореографический симфонизм» в контексте новаторства творческих поисков украинских балетмейстеров-постановщиков 1950-1960-х гг.; выявлены и охарактеризованы методы хореографического симфонизма как новой формы балетного спектакля, а также определен вклад украинских балетмейстеров А. Шекеры, В. Вронского, М. Трегубова, Н. Скорульского и И. Ковтунова в развитие художественно-образных форм отечественного балетного искусства. Выводы. Исследование хореографического симфонизма в контексте обновления украинской балетного театра 50-60-х гг. XX в., на примере постановок ведущих отечественных балетмейстеров, выявило, что отдельные балетные спектакли, массовые или сольные партии построены на разработке хореографических тем с их параллельным развитием и противопоставлением; сочетании хореографических тем с музыкальными; единстве музыкальной и хореографической форм; проведении ритмичности в тактовом и тематическом отношении; совпадении хореографического эмоционального и звуко-эмоционального подъема, а также колоритности инструментовки и танцевальных движений. Элементы балетного симфонизма, проявляющиеся прежде всего в специфической построении композиции, активно интегрировались украинскими балетмейстерами для достижения инновационной хореографической выразительности на основе танца и в соответствии с образностью, структуры музыкальной партитуры.

Ключевые слова: хореографический симфонизм, балет, балетмейстер, композиция, раскрытия образа.

(C) Лук'яненко К.А., 2019 


\section{Lukyanenko Kateryna, Graduate student, Kiev National University of Culture and Arts century) \\ Choreographic symphony in the context of the renewal of the Ukrainian ballet theater (50-60s of the XX}

The purpose of the article is to identify the specifics of integrating the principles of choreographic symphony in the Ukrainian ballet theater during the Khrushchev "thaw." Methodology. The method of historicism is used (to study the process of introducing dance symphony in the context of the particularities of the cultural and historical situation); typological method (which helped to identify the specifics of the construction and composition of dance forms); comparative analysis method (for comparing the methods of revealing the character of a hero through dance in ballet performances on the stages of Ukrainian theaters of the 50-60s of the XX century); method of the stylistic approach (aimed at determining the specifics of the choreographic structure of ballet productions) and other. Scientific novelty. The concept of "choreographic symphony" in the context of the innovation of the creative search for domestic choreographers of the 1950-1960s; the methods of choreographic symphonism as a new form of ballet performance were identified and characterized, and the contribution of the Ukrainian choreographers A. Sheker, V. Vronsky, M. Tregubov, N. Skorulsky and I. Kovtunov to the development of the artistic-figurative forms of Russian ballet art was determined. Conclusions. The study of choreographic symphonism in the context of updating the Ukrainian ballet theater of the 50-60s. The twentieth century, on the example of productions of leading domestic choreographers, revealed that individual ballet performances, mass or solo parts are based on the development of choreographic themes with their parallel development and contrast; combination of choreographic themes with music; unity of musical and choreographic forms; conducting rhythm in tact and thematic terms; coincidence of choreographic emotional and sound-emotional upsurge, as well as colorful instrumentation and dance movements. Elements of ballet symphony, manifested primarily in the specific construction of the composition, were actively integrated by Ukrainian choreographers to achieve innovative choreographic expressiveness based on dance and in accordance with the imagery, the structure of the musical score.

Key words: choreographic symphony, ballet, choreographer, composition, image disclosures.

Актуальність теми дослідження. Хореографічний симфонізм, замінивши на українській балетній сцені хореодраму, протягом другої половини XX ст. сформувався в окремий напрямок, що нині визнаний одним із провідних напрямів світового балетного театру. Багатовимірність та складність цього феномену, появі якого, разом із поняттям інструментальності танцю, змістовності безсюжетного в балеті та загалом основними хореографічними структурами, балетний театр завдячує творчості хореографів-симфоністів 20-х рр. XX ст., лишається не достатньо вивченою, втім як і термінологія. Це актуалізує дослідження балетного симфонізму в контексті історії розвитку вітчизняного балетного мистецтва, визначення специфіки хореографічних форм та еволюціонування засобів виразності.

Мета статті - виявити специфіку інтегрування принципів хореографічного симфонізму в українському балетному театрі за часів хрущовської «відлиги».

Аналіз публікацій. Незважаючи на наявність багатьох публікацій, присвячених особливостям українського балетного театру означеного періоду, проблематика хореографічного симфонізму лишається недостатньо висвітленою. Серед вітчизняних дослідників деякі аспекти симфонізації танцю, а саме театральність та хореографічний симфонізм як принципи розробки мистецької драматургії, розглядав В. Литвиненко («Трансформація української народної хореографії та іï концептуалізація в театрі танцю Павла Вірського») в контексті народно-хореографічного мистецтва. Дослідженню особливостей процесу переходу від принципів хореодрами до симфонізації балету в творчості одного з провідних українських хореографів присвячена наукова публікація Е. Коваленко «Анатолій Федорович Шекера - майстер балетного симфонізму та хореографічної поліфонії». Окремі аспекти означеного питання досліджували С. Павлюк, О. Шаповал, Н. Семенова, Е. Пустова та ін.

Виклад основного матеріалу. Середина 50-х - кінець 60-х рр. ХХ ст. характеризується активізацією розвитку українського балетного мистецтва, формуванням естетичної програми, що тяжіла до увиразнення та урізноманітнення танцювальних форм, виявляючись у зверненні до традицій національної культури, а головне - новаторськими трансформаціями хореографічних стилів, засобів зовнішньої виразності та посиленням художньої образності. Завдяки ослабленню ідеологічної цензури, відповідно до політики М. Хрущова, значно розширюється географічні межі гастрольних виступів; відкриваються нові балетні театри. Спостерігається відчутний відхід від тематики прославлення революції, вождів та радянської влади, звернення балетного мистецтва до теми людської особистості.

Подібні тенденції зумовили кризу жанру хореодрами (елементи драматичної гри, в якому домінували над виключно хореографічними засобами виразності та віртуозним танцем - виконавець намагався передати нюанси стосунків між персонажами та розвиток подій засобами міміки та жестів) як єдиного реалістичного шляху для радянської хореографії та становлення нового типу балетної 
вистави, визначеної В. Вансловим як «хореографічний симфонізм» [12, 104-105]. Відтак, дієвий симфонічний танець стає головним засобом хореографічної виразності. Симфонізація танцю заснована передусім на принципах хореографічного розвитку теми, а не на випадковому наборі танцювальних рухів, незалежно від того, виконуються вони в єдиному ритмі з музикою чи ні.

Одним із перших балетмейстерів, який посприяв формуванню поняття «хореографічний симфонізм», його теоретичному осмисленню в контексті побудови та композиції танцювальних форм за принципами, що аналогічні музичному формотворенню, був Ф. Лопухов. На його думку, симфонізм танцю наявний лише у разі базування постановки на принципі хореографічної тематичної розробки, замість випадкового набору танцювальних рухів, що виконуються в ритм музики $[10,54-$ 55]. Введенню поняття до наукового обігу посприяла діяльність одного 3 перших професійних балетознавців - Ю. Слонімського та відомого театрального критика І. Солертинського.

Сучасне мистецтвознавство визначає симфонізм як естетичну категорію, що передбачає застосування особливого методу художнього відображення дійсності. Відповідно хореографічний симфонізм позиціонується як універсальний засіб найповнішого розкриття художнього задуму 3 допомогою послідовного та цілеспрямованого музичного розвитку, що включає протиборство, розвиток, схрещення та перетворення тем і тематичних елементів [2].

Відомий балетознавець В. Красовська визначає хореографічний симфонізм як багатопланову танцювальну дію в структурних формах симфонічної музики та подібне до неї широке осмислення буття в багатозначних, узагальнених і мінливих образах [7, 123].

Хрущовська «відлига» активізувала проблематику хореографічного симфонізму, який за часів панування та театральній сцені хореодрами позиціонувався як формалістичний підхід до балетної вистави. Цілком очевидно, що розкриття образу героя через танець станом на початок 1950 -х рр. було скоріше винятком, натомість балетну сцену, як головний виражальний засіб, «... заполонила ілюстративна пантоміма, яка, по суті, копіювала побутову поведінку людини» $[9,18]$. Проте невдовзі домінування натуралістичних деталей та побутово-приземлена правдоподібність в балетних виставах нівелюється в порівнянні з новаторською танцювальною образністю, властивою хореографічному симфонізму. У творчості радянських балетмейстерів-постановників він характеризується передусім безперервністю розвитку, абстрактною виразністю танцю, посиленням емоційного піднесення та сонатною формою як провідною в хореографічній композиції.

На думку мистецтвознавців, у масштабі радянського балетного театру найяскравіше симфонічний танець втілено в балетах Ю. Григоровича «Кам'яна квітка» С. Прокоф’єва (1957 р.), «Легенда про любов» А. Мелікова (1961р.), виставах І. Бельського «Берег надії» А. Петрова (1959 р.) та «Ленінградська симфонія» Д. Шостаковича (1961р.) [12, 105]. В Україні розвиток хореографічного симфонізму пов'язаний передусім із діяльністю В. Вронського (головний балетмейстер Київського театру опери і балету імені Т. Шевченка в 1954-1969рр.), А. Шекери (з 1964 р. - балетмейстер Львівського академічного театру опери та балету ім. І. Франка, а з 1966 р. - Київського театру опери i балету імені Т. Шевченка), М. Трегубова (балетмейстер Львівського театру опери та балету в 19501958 рр.) та І. Ковтунова (балетмейстер Харківського театру опери та балету ім. М. Лисенка).

В. Красовська стверджує, що творчість українських балетмейстерів 50-60-х рp. XX ст. посприяла утвердженню симфонічного хореографічного мислення - танець у постановках був мистецтвом, виражальні засоби якого сприяли осмисленню людського життя: «... на зміну примітивним пантомімним виставам з побутовою жестикуляцією, в яких роль танцю зводилася лише до вставного дивертисменту, на українську сцену прийшли твори 3 широко розвиненою танцювальною образністю, що поетично й узагальнено розкривають високі ідеї і почуття» $[8,219]$. Особливо яскраво це виражалося в балетних виставах, де класичний танець поєднувався 3 елементами локальної хореографічної лексики фольклорного танцю.

Так, наприклад, у 1956 р. на сцені Львівського театру опери та балету М. Трегубов здійснив постановку балету «Сойчине крило» А. Кос-Анатольського, за новелою І. Франка (лібрето О. Гериновича), у першій картині якого «... класичний танець, щедро обарвлений гуцульськими хореографічними візерунками, переконливо розкривав внутрішній світ і почуття Манусі (Н. Слободян) і Массіно (О. Поспєлов), захоплював своїм щирим ліризмом і натхненною плинністю» $[11,25]$.

Навесні 1958 р. постановку «Лісової пісні» Лесі Українки в Київському академічному театрі опери і балету ім. Т. Шевченка здійснив В. Вронський, зберігаючи в інтерпретації балету певні аспекти, використані С. Сергєєвим (автор хореографії прем'єрної вистави 1946 р.) та прагнучи до розвитку складних форм хореографічного симфонізму. Балетмейстер, фокусуючи увагу на танці як 
основі для розкриття образів і розвитку колізії вистави, «узагальнену традиційну класику» гармонійно поєднав з елементами народної хореографії $[14,278]$.

Е. Пустова стверджує, що постановка В. Вронського вирізнялася внутрішньою єдністю виражальних засобів, органічного синтезу музичних i хореографічних структур та принципів образного розвитку, а головне - психологічно тонким розкриттям у танці внутрішнього світу героїв та змалюванні їх складних, багатопланових характерів у розвитку [13, 78-79].

Передусім балетмейстер персоніфікує жителів лісового царства (Той хто греблі рве, Русалка водяна, Водяник, Потерчата та ін.) задля створення відповідної атмосфери вистави та вирішує тематику нестримних сил природи завдяки віртуозному танцю. Наприклад, високі стрибки, тури та їх чергування в повітрі з cabriole (стрибок, в процесі якого одна нога підбиває іншу знизу вгору один або кілька разів) та saut de basque (стрибок з однієї ноги на іншу з поворотом корпусу в повітрі) в партії Того, що греблю рве.

Складністю та глибинністю характеру, завдяки комплексу музично-драматичних прийомів балетного жанру, використаного М. Скорульським у процесі створення балетної партитури, вирізняється образ Мавки. Для його розкриття композитор використав лейтмотиви (зауважимо, що це стосується не лише образу героїні та ії душевних станів, а й тем-символів) та об'єднав музичний матеріал з допомогою епізодів, що повторюються, стрункими формами окремих фрагментів та інтегруванням локального національного колориту.

Майстерно, на індивідуально-чуттєвому та технічному рівні образ Мавки було втілено солістками Є. Єршовою, А. Гавриленко, О. Потаповою (перші виконавиці партії у 1950-1960-х рр.). Завдяки виразному танцю та віддзеркаленню в пластичних нюансах відповідного внутрішнього стану кожна 3 артисток створила власну лісову німфу - мрійливо-ліричну та задушевну; тендітну й променисту; натуру внутрішньо сильну, поривчасто-пристрасну та жертовну [15].

Емоційний стан головних героїв під час першої зустрічі (перше розгорнуте адажіо Мавки та Лукаша (М. Апухтін), відповідно до задуму В. Вронського, передається глядачу завдяки виконанню артистами ніжних партерних підтримок, неквапливих обводок в арабеску, парних кружлянь, чітких зупинок у величних, піднесених позах. Під час другого адажіо спалах взаємного кохання, його щирість та нестримність передано особливою піднесеністю поз та рухів, плавними пластичними лініями та високими підтримками $[13,80]$.

Новаторство В. Вронського відобразилося й на зміні функції кордебалету - він втрачає традиційну для хореодраматичного жанру декоративно-зображальну роль, стаючи подекуди рухомою силою постановки, сприяючи розкриттю стану душі та візуально-образному озвученню внутрішнього монологу героїв. Наприклад, варіації Мавки акомпанує розгорнутий ансамбль польових квітів хореографія покликана посилити розкриття внутрішньої боротьби та вагань.

Масові хореографічні картини балету «Лісова пісня» в постановці В. Вронського також засвідчують використання різноманітних форм хореографічного симфонізму. Е. Пустова серед інших визначає принцип танцювальної поліфонії, принцип багатоголосся, принцип контрапункту солістів і кордебалету та принцип розгорнутого ансамблевого акомпанементу [13, 81].

На сцені Харківського театру опери та балету ім. М. Лисенка одним із перших балетмейстерів елементи хореографічного симфонізму застосовує І. Ковтунов під час постановки балету «Таврія» В. Нахібіна в 1959 р. Наприклад, піднесена героїко-романтична варіація головного героя Матроса (В. Гудименко) народжувалася 3 розгорнутого масового танцю батраків. Прагнучи посилити хореографічну виразність та передати нюанси музичного звучання, балетмейстер відходить від усталеної форми класичного танцю, органічно поєднавши традиційні балетні рухи 3 такими елементами народного українського танцю, як «кільце», «високий голубець», «щупак», «стрибок на коліно», «розтяжска в повітрі» та ін., щоправда не порушуючи малюнку [16].

Симфонізмом музичних образів, що передбачає використання виключно розвиненого балетного симфонізму та розгорнутих хореографічних лейтмотивів, замість традиційних прийомів побутово-пантомімічних постановок, характеризується один з найвизначніших українських балетів другої половини XX ст. - «Тіні забутих предків» В. Кирейка. На думку відомого вітчизняного мистецтвознавця Л. Архимович, партитура твору вирізнялася мелодійністю, танцювальністю та емоційністю, глибиною вираження національного характеру, завдяки майстерному перетворенню композитором ладоінтонаційних елементів пісенного фольклору Гуцульщини, приваблюючи увагу постановників можливостями творчої інтерпретації, завдяки наскрізній симфонізації тематичного матеріалу $[1,6]$. Незважаючи на те, що першопрочитання твору балетмейстером Львівського оперного театру Т. Рамоновою в 1960 р. виявилося невдалим саме через уникнення надзвичайних образних можливостей, що надавав хореографічний символізм (постановниця побудувала виставу на 
пантомімі 3 вставними дивертисментами й типовими класичними балетними композиціями), прем’ера на київській оперній сцені в 1963 р., у новій редакції та хореографії Н. Скорульської, вирізнялася новаторським підходом.

Варто зазначити, що в цьому разі балетмейстер-постановник, водночас співавтор сценарію балету (разом із Ф. Коцюбинським), у процесі створення танцювальних образів, які відповідали б настроям балетної партитури, Н. Скорульська враховувала найдрібніші штрихи, окреслені М. Коцюбинським у літературному першоджерелі.

На думку критиків, виконання В. Парсеговим партії Івана відповідало глибинності внутрішнього світу героя - замріяні, піднесені, мужні, іноді трагедійні та сповнені безвихідної туги сольні танцювальні варіації розкривали поетичність натури як головну рису характеру гуцульського парубка, водночас засвідчуючи своєрідність сприйняття гармонії людини та природи, почуттів та вчинків. У рецензіях до вистави знаходимо такий відгук на хореографічну партію Івана: «...польотні класичні рухи, пронизані елементами гуцульського народного танцю. Характерні рухи, різноманітні парні положення ставали основою його класичного адажіо з Марічкою (С. Сршова)» [4].

Варто зазначити, що в процесі постановки балету Н. Скорульська поєднала успішний досвід синтезування класичного й народного гуцульського танцю М. Трегубова (і навіть збагатила його, створивши новітню хореографічну лексику) в сольних варіаціях і дуетах та відтворення автентичних народних гуцульських танців у масових сценах та епізодах (для цього консультантом вистави було запрошено К. Балог). Проте, перенесення «... у спектакль гуцульських танців і обрядів з усіма їхніми етнографічними деталями й побутовими подробицями», на думку критиків, було невдалою ідеєю «... у хореографічній тканині твору з'явилась інтонаційна фальш: адже класична узагальнена мова партій головних героїв мимоволі зіткнулась у конфлікті з конкретними побутовими копіями обрядів і танців» $[6,5]$.

Визнаним майстром танцювального симфонізму українського балетного театру є А. Шекера, постановки якого вирізнялися оригінальністю хореографічного стилю та психологічним умотивуванням вчинків, почуттів та думок персонажів - вади хореодрами балетмейстер вирішував методом засвоєння глибинних принципів музичного мислення $[5,40]$, стверджуючи новаторську лексику та спосіб хореографічного вираження.

На думку Є. Коваленко, створенню дієвих балетних вистав, в яких життєві характери, пов'язані з реальними прототипами, позиціонувалися як засоби виразності умовного балетного театру, А. Шекера завдячував передусім досконалому володінню балетною режисурою та майстерності осягнення специфіки метроритмічної організації та фактурних елементів інструментальної музики $[5,37]$.

Ознаки хореографічного симфонізму наявні вже в дебютній постановці А. Шекери на сцені Київського театру опери і балету в 1967 р. - вистави «Легенда про любов» А. Мелікова. Балетмейстер, розвиваючи поліфонічні принципи (наприклад, класичного кордебалету), використані Ю. Григоровичем у прем’єрній постановці 23 березня 1961 р. на сцені Ленінградського театру опери i балету імені С. М. Кірова, поєднав запропонований сценарний план і партитуру з оригінальною хореографічною лексикою. Наприклад, у партії Мехмене Бану (В. Калиновська) балетмейстер зробив акцент на пластиці тіла, відмовившись від мімічної гри - оскільки обличчя артистки було сховане за півмаскою, найдрібніші нюанси душевних станів героїні вона відтворювала виключно засобами пластичної виразності, прагнучи до емоційного наповнення кожного жесту. В. Калиновська віднайшла унікальний малюнок танцю, відповідно до музичної характеристики складного, багатогранного образу, проникнувши та осмисливши кожен рух $[5,40]$. Відповідно до специфіки хореографічного симфонізму, балетмейстер посилює дієвість жіночого кордебалету. Наприклад, ідеально синхронізовані рухи всіх виконавиць під час монологу цариці символічно відтворювали нав'язливі гнітючі думки головної героїні, що своєрідно відображало взаємозв'язок музичних тем, мінливість емоційної складової та ритмічної пульсації.Новаторство діяльності провідних українських балетмейстерів 1950-1960-х рр. засвідчує звернення до хореографічного симфонізму передусім у контексті осучаснення композиційного малюнка та розробки власних методів розкриття художнього образу відповідно до специфіки індивідуального творчого бачення.

Наукова новизна. Розглянуто поняття «хореографічний симфонізм» у контексті новаторства творчих пошуків українських балетмейстерів-постановників 1950-1960-х рр.; виявлено та охарактеризовано методи хореографічного симфонізму як нової форми балетної вистави, а також визначено внесок українських балетмейстерів А. Шекери, В. Вронського, М. Трегубова, Н. Скорульської та І. Ковтунова в розвиток художньо-образних форм вітчизняного балетного мистецтва. 
Висновки. Дослідження хореографічного симфонізму в контексті оновлення українського балетного театру 50-60-х pp. XX ст. на прикладі постановок провідних вітчизняних балетмейстерів-постановників виявило, що окремі балетні вистави, масові чи сольні партії побудовані на розробці хореографічних тем з їх паралельним розвитком та протиставленням; поєднанні хореографічних тем з музичними; єдності музичної та хореографічної форм; проведенні ритмічності в тактовому та тематичному відношенні; збігу хореографічно-емоційного та звуково-емоційного підйому, а також колоритності інструментування та колоритності танцювальних рухів. Елементи балетного симфонізму, що проявляються передусім у специфічній побудові композиції, активно інтегрувалися українськими балетмейстерами задля досягнення інноваційної хореографічної виразності на основі танцю та відповідно до образності й структури музичної партитури.

\section{Лiтература
1. Архимович Л. Виталий Кирейко. Москва: Советский композитор, 1968. 10 с.}

2. Валукин М. Проблемы танщевального симфонизма. Балет: Литературно-критический, историкотеоретический иллюстрированный журнал. 2009. № 6. С. 14-15.

3. Габович М. Душой исполненный полет. Москва: Искусство,1966. 230 с.

4. Гордейчук Н. Сплав поэзии, музыки, танца. Правда Украины. 1963. 12 мая.

5. Коваленко Е. И. Анатолий Федорович Шекера - мастер балетного симфонизма и хореографической полифонии. Южнно-Российский музыкальный альманах. 2016. № 1 (22). С. 37-42.

6. Коваленко Ю. Тіні ожили на сцені. Україна. 1963. № 10. С. 5-7.

7. Красовская В. Статьи о балете. Ленинград : Искусство, 1967. 340 с. C. 218-248.

8. Красовская В. В середине века (1950-1960-е годы). Советский балетный театр. Москва: Искусство, 1976.

9. Красовская В. Осторожно, классика! Музыккальная жизнь. 1981. № 21. С. 18.

10. Лопухов Ф. Пуги балетмейстера. Берлин : Петрополис, 1925. 179 с. 2017. $230 \mathrm{c}$.

11. Павлюк Т.С. Українське балетмейстерське мистецтво (II половина XX ст.). Київ : Вид. центр КНУКіМ,

12. Предеина Т. Б. Вопросы периодизации истории отечественного балета XX - XXI веков. Вестник Челябинской государственной академии культуры и искусства. 2013. № 1 (33). С. 103-108.

(24). C. $78-86$.

13. Пустова Е. Півстоліття на балетній сцені. Студії мистецтвознавчі. Київ : ІМФЕ НАН України, 2008. № 4

14. Станішевський Ю. Український радянський музичний театру (1917-1967): нариси історії. Київ, 1970. 291 с.

15. Станішевський Ю. Поет танцю (Творчий портрет народного артиста СРСР В. Вронського). Центральний державний архів-музей літератури і мистецтв україни. Ф. 563. Оп. 1. Спр. 109.

16. Сироткін В. Герої О. Гончара в балеті. Соџіалістична Харківщина.1959. 17 черв.

\section{References}

1. Arkhimovich, L. (1968). Vitaliy Kireyko. Moscow: Soviet composer. [in Russian].

2. Valukin, M. (2009) Problems of dance symphony. Ballet : Literary-critical, historical-theoretical illustrated magazine, no. 6, pp. 14-15. [in Russian].

3. Gabovich, M. (1966). Soul performed flight. Moscow. [in Russian].

4. Gordeychuk, N. (1963). Alloy of poetry, music, dance. True Ukraine. [in Russian].

5. Kovalenko, E. I. (2016). Anatoly Fedorovich Sheker - master of ballet symphony and choreographic polyphony. South Russian musical almonah, no. 1 (22), pp. 37-42. [in Russian].

6. Kovalenko, Y. (1963). Shadows came to life on stage. Ukraine, no. 10, p. 5-7. [in Ukrainian].

7. Krasovskaya, V. (1967). Articles on ballet. Leningrad: Art. [in Ukrainian]. [in Russian].

8. Krasovskaya, V. (1976). In the middle of the century (1950-1960s). Soviet ballet theater. Moscow: Art, pp. 218-248.

9. Krasovskaya, V. (1981). Caution, classic! Music life, no. 21, p. 18. [in Russian].

10. Lopukhov, F. (1925). Ways of the choreographer. Berlin: Petropolis. [in Russian]. Ukrainian].

11. Pavlyuk, T. S. (2017). Ukrainian Ballet Art (2nd half of the 20th century). Kiev: Publishing center KNUCA. [in

12. Predeina, T. B. (2013). Issues of periodization of the history of domestic ballet of the 20th - 21st centuries. Bulletin of the Chelyabinsk State Academy of Culture and Art, no. 1 (33), pp. 103-108. [in Russian].

13. Pustova, E. (2008). Half a century on the ballet stage. Art Studies Studios. Kiev: IMFE NAS of Ukraine, no. 4 (24), pp. 78-86. [in Ukrainian].

14. Stanishevsky, Y. (1970). Ukrainian Soviet Music Theater (1917-1967): Essays on History. Kyiv. [in Ukrainian].

15. Stanishevsky, Y. The poet of dance (Creative portrait of the People's Artist of the USSR V. Vronsky). Central State Archive-Museum of Literature and Arts of Ukraine. F. 563. Op. 1. Ref. 109. [in Ukrainian].

16. Sirotkin, V. (1959). Heroes of O. Gonchar in ballet. Socialist Kharkiv region, Jun 17. [in Ukrainian]. 